\title{
Seepage stability study on gravel soil slope in Jin'an bridge station reservoir
}

\author{
W.C. Xu ${ }^{1}$, L.H. Zhang ${ }^{1}$, J.H. Chen ${ }^{2}$, Xueyu Dai ${ }^{3}$ \\ ${ }^{1}$ Kunming University of Science and Technology, Kunming Yunnan, 650500, China \\ ${ }^{2}$ Yunnan transportation consulting co., LTD, Kunming, 650500, China \\ ${ }^{3}$ Kunming Engineering Corporation limited of China Power Group Corp, Kunming, 650500, China
}

Keywords: reservoir ban; seepage; stability; water level fluctuation; gravel soil.

\begin{abstract}
Jin' an bridge station is located at the middle reaches of Jinsha river which is a new super large hydro-power station, since impounded in 2012, different levels of landslide happened to the reservoir slope, and the change of seepage field is one of the main reason causing geo-hazards. In this paper, according to the engineering investigation, using the soil-water characteristic curve, build a two-dimensional saturated-unsaturated seepage model of gravel soil slope in reservoir, which simulated the evolution course of the seepage and stability in the initial filling, normal operating and falling period, analyzed the influence of the saturation line and slope safe-ty factor caused by the water level fluctuation. Research shows that: In the initial filling, the saturation line presents as lower convex and the slope safety factor presents monotonic increase. In the normal operating, the saturation line tend to be gentle gradually and the slope safety factor presents monotonic increase. In the falling period, the saturation line presents as upper convex and the slope safety factor presents monotonic de-crease. In every period of time, the slope safety coefficient is less than 1, which shows landslide could hap-pen. The draw-down velocities is inversely correlated with slope stability.
\end{abstract}

\section{Introduction}

Jinsha River, the reservoir is a typical mountain canyon V-shaped valley terrace of the terrain. Power station formally switch-off water storage on January 1, 2012,Storage period has 6 months, the water lever rise $64.5 \mathrm{~m}$, which from the original water level $(1353.5 \mathrm{~m})$ to the normal storage level (1418m), and running under the normal storage level up to now. According to the engineering-geological investigation, in the process of hydro-power station filling and falling water, different levels of landslide happened to the reservoir slope which from Lijiang to Kaiyuan bridge in Ninglang, the width of landslide is range from $2 \sim 15 \mathrm{~m}$, the depth is range from $8 \sim 30 \mathrm{~m}$, and the slope angle is range from $37^{\circ} \sim 53^{\circ}$, which is a typical towed gravel soil landslide. All kinds of deformation is widely distributed, which could be a threat to the stability of the proposed highway, as shown in figure 1.For now, the landslide has become the most serious and the most common geological disasters, and the change of seepage field is one of the main reason causing geo-hazards. So it is necessary to study the evolution process of seepage and slope stability for the reservoir region.

\section{Project summary}

According to the power station hydro-logical data, the check flood level is $1421 \mathrm{~m}$, the normal storage level is $1418 \mathrm{~m}$, dead water level is $1398 \mathrm{~m}$.In 2013 , the highest water level is $1417.9 \mathrm{~m}$, the lowest water level is 1405.9.According to drilling, groundwater shows in every drilling, the underground water level is between $1412.55 \mathrm{~m} \sim 1414.13 \mathrm{~m}$. Groundwater is supplied by the bedrock fissure water and reservoir water and affected by water level fluctuation.

The study area is located in the deep cutting area of the $\mathrm{V}$-shaped high valley in Jinsha River. Distribution of middle Permian emeishan basalt group $\left(P_{2} \beta^{2}\right)$ : dark gray, gray, green, purple, green and yellow dense, brecciated basalt, basalt of lenticular limestones. Overlying quaternary remnants diluvial layer $\left(Q^{4 e l+d l}\right)$ : gray, brown, brown, gray breccia, gravel, thickness of $0.2 \sim 83.5 \mathrm{~m}$. 
Drilling reveal layer: Gravel 1: gray green, brown, gray, slightly Micronesia, slightly wet, local clip 3 5\% boulder, gravel, sand and cohesive soil. Containing 51\% 71.2\% of weathering basalt, shale fragments, angular fillings of cohesive soil and sandy soil.

Gravel 2: gray green, brown, gray, compact shape, wet to saturated soil, the partial clip 5 10\% boulder, gravel, sand and cohesive soil. Containing $51 \% \sim 71.2 \%$ of weathering basalt, shale fragments, angular fillings of cohesive soil and sandy soil. Grain size distribution of Gravel 1 and gravel 2 as shown in table 1.
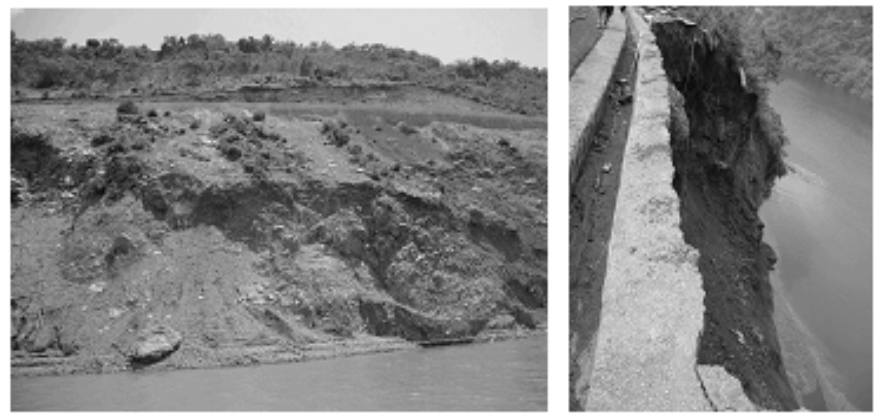

Fig.1 Site photograph for landslide in the reservoir

Basalt: middle Permian Emei mountain basalt group $\left(P_{2} \beta^{2}\right)$ : gray, green, blue, brown, medium to weak weathering, is broken, the RQD $=3 \%$, main structural plane as joint, cranny, quartz vein, filling iron magnesia impregnation. Drilling depth range from $61.7 \mathrm{~m}$ to $61.7 \mathrm{~m}$.

Table 1 Grain size distribution of gravel soil (\%)

\begin{tabular}{cccccc}
\hline $\begin{array}{c}\text { Grain size } \\
\text { distribution } \\
(\mathrm{mm})\end{array}$ & $200 \sim 20$ & $20 \sim 2$ & $2 \sim 0.5$ & $0.5 \sim 0.075$ & $<0.075$ \\
\hline Gravel 1 & 81.5 & 5.9 & 0.8 & 1 & 10.8 \\
Gravel 2 & 80.4 & 6.5 & 0.9 & 1.2 & 11 \\
\hline
\end{tabular}

\section{The slope saturated-unsaturated seepage mode in reservoir}

In the reservoir seepage slope stability calculation, using the limit equilibrium method of Morgenstern-Price method, the slide function is half-sine function $\mathrm{f}(\mathrm{x})=0.5 \sin x$; Using Fredlund's theory of double variable formula of shear strength; Seepage boundary is: Above the water level is zero flow boundary, under the water level is constant head boundary following, the other which is not stated impermeable boundary is defined as the boundary, the initial head of the Jinsha River water level of the original $1353.5 \mathrm{~m}$; selection triangular and quadrilateral elements, generating a total of two-dimensional percolation model 10317 grid cells, 10,417 nodes; paper Jin'an bridge station Reservoir exploration Lining highway fifth section for calculating profiles percolation model shown in Figure 2.

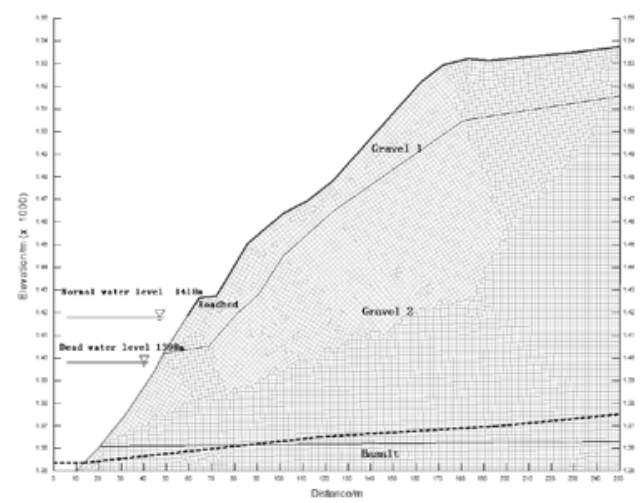

Fig.2 The seepage model of slope in Jin'an reservoir

In this paper, engineering geological analogy, based on the grain size distribution of gravel soil slope inquire SWCC, combined with saturated hydraulic conductivity, permeability prediction selection of Van Genuchten model to obtain the slope of unsaturated hydraulic conductivity, shown 
in Figure 3. In this paper do this inversion method, combining engineering survey and drilling data obtained saturated hydraulic conductivity, other soil mechanics parameters are soil test values. Model material parameters values shown in Table 2.

Table 2 Material parameters of slope

\begin{tabular}{cccccc}
\hline Material & Satu & Natural density \\
parameter & $\gamma /\left(\mathrm{kN} \cdot \mathrm{m}^{-3}\right)$ & $\begin{array}{c}\text { ration } \\
\text { density } \\
\gamma_{\text {sat }} /\left(\mathrm{kN} \cdot \mathrm{m}^{-3}\right)\end{array}$ & $\begin{array}{c}\text { Effective } \\
\text { cohesion } \\
\mathrm{c}^{\prime} / \mathrm{kPa}\end{array}$ & $\begin{array}{c}\text { Effective } \\
\text { internal } \\
\text { friction angle } \\
\varphi^{\prime} /\left(^{\circ}\right)\end{array}$ & $\begin{array}{c}\text { Saturation } \\
\text { Permeability } \\
\text { coefficient } \\
\mathrm{k}_{\mathrm{s}} /\left(\mathrm{cm} \cdot \mathrm{s}^{-1}\right)\end{array}$ \\
\hline Gravel 1 & 19.8 & 20.4 & 13.3 & 30.7 & $9.26 \times 10^{-4}$ \\
Gravel 2 & 21.4 & 21.9 & 15.3 & 30.7 & $2.32 \times 10^{-4}$ \\
Basalt & 26.7 & 27.1 & 1420 & 45.3 & $9.26 \times 10^{-5}$ \\
\hline
\end{tabular}

\section{Numerical simulation and analysis}

In this paper, simulated the evolution course of the seepage and stability in the initial filling (180 days) - normal operating (520 days) - falling the water (20 days), the water level was rising and constant running water, and the water level decline rate is $4 \mathrm{~m} / \mathrm{d}$ and $1 \mathrm{~m} / \mathrm{d}$, the slope saturation line changes with time chart, Figure 4(a),(b),(c) below. Reservoir seepage slope evolution for different periods are as follows:

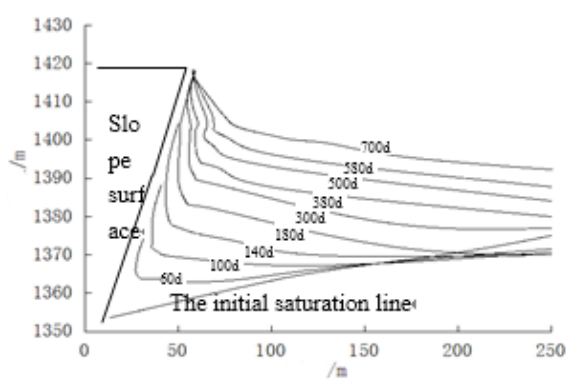

(a) The saturation line change during the water level rises and stable

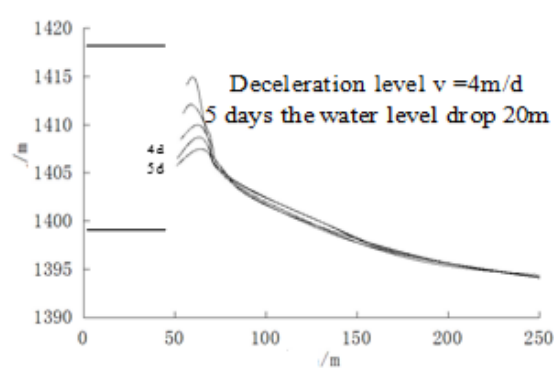

(b)The saturation line change when drawdown rate is $4 \mathrm{~m} / \mathrm{d}$

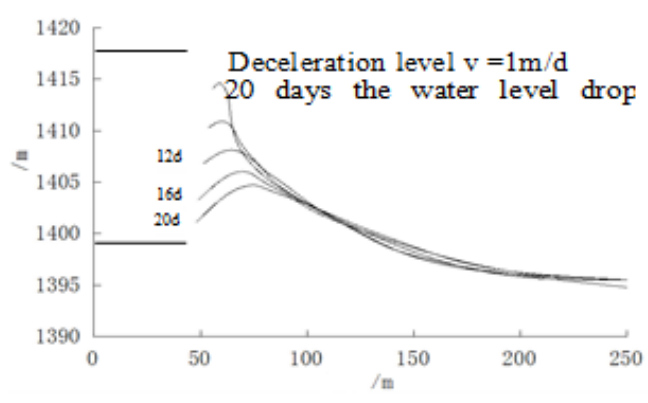

(c) The saturation line change when drawdown rate is $1 \mathrm{~m} / \mathrm{d}$

Fig 4 the change of the saturation line of the slope 
(1) Initial water, time for 0 to 180 days, the original reservoir levels Jinsha river water level rose from 1353.5 meters to the normal water level $1418 \mathrm{~m}$. As can be seen from Figure 4 (a), in the flow field, the slope of saturation line with the overall increase in the water level rises to show the law, saturated line shape is obviously convex. Not before the reservoir water, groundwater recharge Jinsha perennial subject slope, the water table is higher than the initial slope of the river water (seepage field in the initial invasion line is drawn based on engineering experience). Storage process, with the water levelrises, the slope began by groundwater reservoir water supply, the slope seepage occurs, causing changes in seepage field: slope hydro-static pressure gradually increased, gradually rising slope saturation line, the saturated zone area increases, the unsaturated zone area decreases, the slope around the pore water pressure increases, causing the matric suction decreases. Hysteresis effect refers to the water table seepage water level change lags behind the changes, which affect the morphology of invasive lines. The difference between saturation line forms characterize the different water content of the slope, it will cause a lot of poor matric suction, which have a certain impact on the slope of the shear strength and the safety factor. As can be seen from Figure 4 (a), the storage period (0 180d), due to the lag effect of seepage, slope surface to reach saturation, while the interior is still a non-saturated slope, showing relatively slope faces pressure high, while the internal pore pressure is relatively low slope characteristics, infiltration lines obviously convex shape.

(2) Constant water level, the time for 180 to 700 days, the reservoir water level is maintained at a constant level $1418 \mathrm{~m}$ run. As can be seen from Figure 4 (a), the slope of saturation line over time increases the overall performance of the law, infiltration line shape gradually leveling off. During a constant water level, slope hydro-static pressure remains constant, but the slope seepage field change still occurs: Over time, the slope of saturation line continued uplift, to further increase the saturation area, unsaturated area is further reduced, slope around the pore pressure significantly increases internal body gradually saturated slope, infiltration line performance by significantly lower convex shape gradually leveled off, gradually moving towards saturation line bump inside and upper slope direction.

(3) Drainage of the simulated reservoir water level from the normal water level dropped to dead level $1418 \mathrm{~m} 1398 \mathrm{~m}$, a drop of 20 meters. In this paper, when the water level drops to the same elevation (1414m, 1410m, 1406m, 1402m, 1398m), the precipitation rate of change of saturation line in Figure $4 \mathrm{~m} / \mathrm{d}$ and $1 \mathrm{~m} / \mathrm{d}$ of Figure 4 (b), (c) as shown. Two figure showing a unified law line with the falling water infiltration showed declining law, saturation line obviously convex shape, similar to a parabolic shape. Seepage saturation area decreases, the unsaturated zone area increases, the slope of the overall pore pressure decreases, the matric suction increases, causing the bulk density reduction and contribution to the unsaturated zone shear strength increases; saturation line bump move to the inside and bottom of the slope direction over time. The difference is that the water level in the same period of deceleration is $1 \mathrm{~m} / \mathrm{d}$ corresponding drop in the water level of saturation line deceleration is $4 \mathrm{~m} / \mathrm{d}$ decline compared to the corresponding saturation line small bump saturation line moving more slowly. Precipitation rate determines the slope drainage time, the water level drops to the same elevation, precipitation rate, the longer the slope drainage time, the smaller the saturation line decline; on the contrary, the shorter the drainage slope, the greater the saturation line decline.

\section{Conclusion}

Jin'an bridge station is located in the middle reaches of the Jinsha new large hydro-power, water since 2012, the slope Gorges geological disasters occurred in many different degrees. By studying Reservoir gravel soil slope seepage evolution following conclusions:

In poor permeability rock slope conditions, the initial reservoir storage process, saturation line with the rise in the water level rises to show lower saturation line convex shape; the normal water level process, saturation line as time goes on exhibit increased infiltration line form to flatten; the drainage period, saturation line with a declining water level dropped, the saturation line convex shape. 


\section{References}

[1] BAO C G. 2004. Behavior of unsaturated soil and stability of expansive soil slope.Chinese Journal of Geotechnical Engineering,26(1):1-15.

[2] D.G.Fredlund. 1993. Soil Mechanics for Unsaturated Soils. John Wiley \& Sons. Osman A M. 1988. Riverbank stability analysis I: theory. Journal of Hydraulic Engineering,114 (2): 134-150.

[3] John Krahn. 2004. Seepage Modeling with SEEP/W. GEO-SLOPE International Ltd.

[4] MA C W. 2000. The influence of water level changing on the stability of river embankment .Journal of Lanzhou University (Natural Sciences), 36(3):56-60.

[5] M. Th. Van Genuchten. 1980. A closed-form Equation for predicting the Hydraulic Conductivity of Unsaturated Soils. Soils Science Society of America Journal, 44:892-898.

[6] XU J C.2006. Influence of permeability of gravel soil on debris landslide stability. Chinese Journal of Rock Mechanics and Engineering,25(11):2264-2271. 